\title{
PENINGKATAN PEMBELAJARAN MATEMATIKA MELALUI LITERASI DIGITAL
}

\author{
Farah Indrawati ${ }^{1)}$, Nurul Hikmah ${ }^{2)}$, Mailizar $^{3)}$ \\ Pendidikan Matematika, Fakultas Matematika dan IPA, Universitas Indraprasta PGRI
}

\begin{abstract}
Abstrak
Kegiatan pengabdian kepada masyarakat yang berjudul "Peningkatan Pembelajaran Matematika melalui Literasi Digital" ini bertujuan untuk memberikan kesadaran kepada pendidik akan pentingnya literasi digital dalam peningkatan pembelajaran matematika, serta memberikan pengetahuan dan keterampilan kepada pendidik mengenai aplikasi teknologi dalam pembelajaran matematika. Kegiatan dilakukan dengan metode pelatihan melalui zoom meeting bersama mitra SMK Telekomunikasi Telesandi, Bekasi, pada tanggal 22 Oktober 2020. Kegiatan ini menyadarkan pendidik akan pentingnya peningkatan pembelajaran matematika melalui literasi digital. Pelaksanaan kegiatan berhasil membuka wawasan dan menambah ilmu pengetahuan pendidik untuk terus menyesuaikan diri dengan perkembangan teknologi yang ada dalam mengelola pembelajaran, sehingga dapat melahirkan generasi penerus yang produktif, sesuai dengan yang dibutuhkan pada zamannya.
\end{abstract}

Kata Kunci : Pembelajaran, Matematika, Literasi Digital

\begin{abstract}
This community service activity entitled "Improving Mathematics Learning through Digital Literacy" aims to provide awareness to educators of the importance of digital literacy in improving mathematics learning, as well as providing knowledge and skills to educators regarding the application of technology in mathematics learning. The activity was carried out using a training method through a zoom meeting with partners of SMK Telekomunikasi, Bekasi on October 22, 2020. The activity makes educators aware of the importance of improving mathematics learning through digital literacy. The implementation of activity has succeeded in opening up insight and adding to the knowledgeof educators to continue to adapt to existing technological developments in managing learning, so that it can give birth to a productive future generations, in accordance with what is needed in their era.
\end{abstract}

Keywords: Learning, Mathematics, Digital Literacy

Correspondence author: Farah Indrawati, farah_indrawati@yahoo.com, Jakarta, Indonesia

(1) (2)

This work is licensed under a $C C-B Y-N C$

\section{PENDAHULUAN}

Indonesia adalah salah-satu negara yang mempunyai jumlah konsumen internet terbesar di dunia. Hal tersebut diketahui dari hasil riset dan laporan : 1) Asosiasi Penyelenggara Jasa Internet Indonesia (APJII) bekerja-sama dengan Pusat Kajian Komunikasi (Puskakom) Universitas Indonesia yang mengatakan bahwa total jumlah konsumen Internet pada awal 2015 di Indonesia adalah 88,1 juta orang, kemudian 2) 
Wearesocial.sg pada tahun 2017 yang mencatat sejumlah 132 juta konsumen internet yang terdapat di Indonesia, dan angka ini bertambah sejumlah $51 \%$ dalam kurun waktu satu tahun, dan 3) Digital 2020 dalam We are Social dan Hootsuite mengatakan bahwa populasi konsumen internet di Indonesia menduduki peringkat ketiga di dunia dengan waktu penggunaan internet rata-rata hampir 8 jam ( 7 jam 59 menit) per hari. Beberapa data tersebut menjadikan adanya internet merupakan suatu tantangan yang besar bagi masyarakat Indonesia, terutama pemerintah, pendidik dan orang-tua, yang mempunyai tanggung-jawab dan berperan aktif dalam membentuk generasi yang dibutuhkan pada abad ke-21, yaitu generasi yang mempunyai kompetensi digital dalam menghadapi perkembangan teknologi yang terus meningkat.

Salah-satu indikator pencapaian bidang pendidikan dan kebudayaan di Indonesia adalah keberhasilan dalam membangun literasi digital. Literasi menurut National Institute for Literacy memberikan pemahaman pada kemampuan individu dalam membaca, menulis, berhitung, dan berbicara, serta penyelesaian permasalahan pekerjaan, keluarga, dan masyarakat, atau memberikan respon kepada lingkungannya. Individu dapat membaca dunia dengan memaknai literasi. Digitalisasi merupakan media yang digunakan praktik literasi untuk menghasilkan teks berbasis cetak. Generasi yang terbentuk dari akses yang tidak terbatas dalam teknologi digital akan mempunyai pola pikir yang berbeda dengan generasi sebelumnya, sehingga literasi digital akan menciptakan tatanan masyarakat yang berpandangan kritis dan kreatif. Setiap individu harus memahami bahwa literasi digital merupakan salah-satu hal penting mendasar untuk dapat berpartisipasi dalam perkembangan dunia modern saat ini. Literasi digital pada hakikatnya sama dengan membaca, menulis, berhitung, dan disiplin ilmu lainnya, sebagaimana hasil kesepakatan World Economic Forum (2015) yang mengatakan bahwa literasi digital merupakan salah-satu literasi pokok yang harus diketahui dan dikuasai oleh masyarakat.

Literasi digital adalah kemahiran menggunakan media digital, atau jaringan dalam menemukan, mengevaluasi, membuat informasi, dan memanfaatkannya secara bijak, sehingga dapat terbina suatu hubungan baik dalam kehidupan sehari-hari. Cam dan Kiyici (2017) mendefinisikan literasi digital sebagai keterampilan dan pengetahuan teknologi bagi individu agar dapat mengembangkan aktivitas belajar jangka panjang dan berkonstribusi baik kepada masyarakat. Douglas A.J. Belshaw (2011) dalam tesisnya mengatakan bahwa pengembangan literasi digital membutuhkan delapan elemen esensial sebagai berikut : 1) Kultural (pemahaman keragaman konteks pengguna dunia digital), 2) Kognitif (daya pikir dalam menilai konten), 3) Konstruktif (penciptaan yang mutakhir), 4) Komunikatif (pemahaman kinerja terkait dunia digital), 5) Kepercayaan diri yang responsibel, 6) Kreatif (melakukan hal baru dengan cara baru), 7) Kritis dalam menyikapi konten, serta 8) Tanggung-jawab sosial. Kultural merupakan elemen terpenting dalam pengembangan literasi digital. Hal tersebut disebabkan oleh adanya keterkaitan antara elemen kultural dan elemen kognitif. Elemen kultural dapat membantu elemen kognitif dalam menilai konten.

UNESCO mengatakan bahwa konsep literasi digital merupakan dasar pengelolaan kemampuan dalam memahami perangkat-perangkat teknologi, informasi, dan komunikasi. Konsep literasi digital tidak terlepas dari kegiatan yang terkait dalam dunia pendidikan, seperti membaca, menulis, dan berhitung. Hal tersebut disebabkan oleh karena literasi digital merupakan kecakapan (life skills) yang melibatkan kemampuan bersosialisasi, kemampuan pembelajaran, kemampuan bersikap, kemampuan berpikir kritis, dan kreativitas sebagai kompetensi digital. Konsep literasi digital ini dapat 
dikembangkan melalui dua pendekatan, yaitu : pendekatan konseptual dan pendekatan operasional. Pendekatan konseptual berfokus kepada bidang perkembangan koginitif dan sosial emosional, sedangkan pendekatan operasional berfokus kepada kemampuan praktik penggunaan media itu sendiri yang tidak mungkin diabaikan. Prinsip dasar yang digunakan dalam pengembangan konsep literasi digital adalah : 1) Kemampuan mengekstrak gagasan secara implisit dan eksplisit dari media, 2) Kemampuan menghubungkan antara beberapa bentuk media yang ada secara kemahiran, implisit, keutuhan, dan ketepatan, 3) Kemampuan sosialisasi yang menunjukkan kepribadian atau pendistribusian informasi (mencari, berbagi, dan menyimpan informasi), serta akhirnya dapat membentuk atau membuat ulang media tersendiri, dan 4) Kemampuan mengelola pembicaraan mengenai penyimpanan informasi yang selanjutnya berpotensi sebagai kurasi sosial yang dapat menemukan, mengumpulkan, serta mengorganisasikan informasi bernilai.

Pembelajaran melalui literasi digital yang terintegrasi dengan kurikulum perlu dilakukan di lembaga pendidikan sejak usia dini, terutama dalam pembelajaran matematika. NCSM (2015) mengatakan bahwa literasi digital dapat membantu memahami matematika dan menjadikan matematika sebagai suatu permainan praktis, kompetisi dan latihan. Muliawanti dan Kusuma (2019) mengatakan bahwa literasi digital dapat membangun pola pikir kritis matematika dalam mendapatkan informasi yang bermutu dan relevan, selain membangun keterampilan ilmu pengetahuan. Matematika merupakan ilmu semesta yang mendasari pertumbuhan teknologi mutakhir dan dapat meningkatkan daya pikir, serta mempunyai peran yang sangat penting dalam perkembangan berbagai disiplin ilmu. James dan James dalam Hasanah (2010: 11) mengatakan matematika adalah ilmu nalar mengenai bentuk, susunan, besaran, dan konsep-konsep yang saling terkait dalam jumlah besar dan terbagi ke dalam tiga bidang, yaitu aljabar, analisis, dan geometri. Lerner dalam Ugi (2016:36) mengatakan bahwa kurikulum dalam pembelajaran matematika hendaknya mencakup : 1) Konsep pemahaman dasar, 2) Keterampilan dalam kinerja yang dapat ditingkat melalui latihan, dan 3) Pemecahan masalah yang merupakan penerapan dari konsep dan keterampilan dalam suatu situasi. Sumardyono dalam Kania (2018:10) mengatakan bahwa ciri atau karakteristik matematika adalah : 1) Mempunyai objek kajian abstrak dalam fakta, operasi atau relasi, konsep, dan prinsip, 2) Bertumpu pada suatu kesepakatan sehingga mudah dikomunikasikan, 3) Berpola pikir deduktif yang berpangkal dari suatu hal bersifat umum diarahkan kepada hal bersifat khusus, 4) Mempunyai simbol kosong yang mengandung makna jika dikaitkan dengan konteks tertentu, sehingga mempunyai kekuatan dalam berbagai bidang kehidupan, 5) Memperhatikan semesta pembicaraan, serta 6) Mempunyai sistem yang konsisten. Penyajian pembelajaran matematika di lembaga pendidikan tentunya harus disesuaikan dengan perkembangan intelektual peserta didik.

Literasi digital di lembaga pendidikan harus dikembangkan sebagai mekanisme pembelajaran yang terintegrasi dalam kurikulum, atau terkoneksi dengan sistem pembelajaran. Kerja-sama antara pemerintah, pemimpin lembaga pendidikan, pendidik, orang-tua dan peserta didik sangat dibutuhkan dalam hal ini. Peserta didik harus dapat meningkatkan keterampilannya, sementara pendidik harus meningkatkan pengetahuan dan kreativitasnya dalam proses pengajaran atau pembelajaran literasi digital, disamping adanya pemenuhan fasilitas yang diberikan oleh pemimpin lembaga pendidikan dan orang-tua sesuai dengan kurikulum yang telah ditetapkan oleh pemerintah. Beberapa hal yang telah diungkapkan tersebut menjelaskan bahwa peningkatan pembelajaran melalui 
literasi digital sangatlah penting, terutama dalam pembelajaran matematika. Kesesuaian antara konsep, karakteristik dan kurikulum pembelajaran, serta tingkat intelektual pendidik dan peserta didik merupakan suatu hal penting yang harus diperhatikan karena terkait dengan penyampaian dan penerimaan informasi. Penyajian informasi materi pembelajaran matematika yang jelas dan menarik dapat meningkatkan motivasi diri peserta didik untuk terus belajar, sehingga dapat meningkatkan hasil pembelajaran, serta mampu menyelesaikan permasalahan-permasalahan kehidupan sehari-hari. Penerapan literasi digital dalam pembelajaran matematika ini merupakan salah-satu solusi dalam meningkatkan pembelajaran matematika, yang selanjutnya dapat membentuk watak, peradaban dan meningkatkan mutu generasi penerus sehingga sesuai dengan yang dibutuhkan di era globalisasi.

Permasalahan mitra saat ini adalah pembelajaran yang sepenuhnya belum membuat peserta didik aktif. Pendidik dan peserta didik secara mandiri belum menerapkan sistem pembelajaran melalui literasi digital. Pelaksana kegiatan juga masih menjumpai sebagian besar pendidik belum atau tidak terampil, kreatif, dan inovatif dalam mendapatkan informasi, serta memilih model pembelajaran secara tepat terkait pemanfaatan teknologi yang sesuai dengan materi pembelajaran. Permasalahan mitra selanjutnya adalah mitra belum dapat sepenuhnya memfasilitasi pengembangan budaya literasi digital. Beberapa permasalahan tersebut menyebabkan mitra perlu melakukan perubahan dalam sistem pembelajaran. Perubahan dalam sistem pembelajaran yang dimaksudkan disini adalah perubahan sistem pembelajaran yang lebih diarahkan kepada literasi digital yang menggunakan aplikasi teknologi, yang selanjutnya dapat meningkatkan hasil pembelajaran. Hal ini tentunya harus dilakukan dalam menciptakan kondisi pembelajaran yang kondusif dan generasi penerus yang dibutuhkan di era globalisasi.

Tujuan dari kegiatan ini adalah memberikan kesadaran kepada pendidik akan pentingnya literasi digital dalam peningkatan pembelajaran matematika, serta ilmu pengetahuan dan keterampilan kepada pendidik mengenai aplikasi teknologi dalam pembelajaran matematika. Solusi yang ditawarkan dalam kegiatan ini adalah kesadaran terhadap pendidik akan pentingnya peningkatan pembelajaran matematika melalui literasi digital saat ini. Pendidik harus dapat membangun pemahaman baru peserta didik secara aktif dalam pembelajaran melalui aplikasi teknologi yang terus mengalami perkembangan. Berbagai informasi yang diberikan oleh pendidik, terutama yang berkaitan dengan peningkatan pembelajaran matematika, merupakan salah-satu kontribusi yang sangat membantu tim pelaksana dalam membuat rancangan kegiatan penyelesaian permasalahan. Salah-satu kegiatan yang dilakukan oleh tim pelaksana untuk menyelesaikan permasalahan yang ada tersebut adalah pelatihan mengenai peningkatan pembelajaran matematika melalui literasi digital dengan menggunakan fasilitas komputer atau laptop, smartphone dan internet bagi pendidik. Kesadaran dan kemampuan pendidik untuk terus menggali dan mengembangkan potensi diri dalam menciptakan pembelajaran kreatif, kritis dan mandiri dengan penggunaan aplikasi teknologi yang tepat, efisien, efektif dan sesuai, merupakan salah-satu hal yang sangat penting dalam rangka meningkatkan hasil pembelajaran. Pendidik dan peserta didik diharapkan akan menjadi lebih aktif, kreatif, dan antusias dalam mengikuti pembelajaran. Tidak hanya itu, tim pelaksana kegiatan juga mempunyai target luaran untuk mempublikasikan laporan yang dibuat dari pelaksanaan kegiatan pelatihan ini kedalam jurnal ilmiah nasional yang terakreditasi SINTA. 


\section{METODE PELAKSANAAN}

Kegiatan ini dilaksanakan pada tanggal 22 Oktober 2020. Tim pelaksana melakukan zoom meeting dengan mitra, yaitu SMK Telekomunikasi Telesandi, yang beralamat di Jalan KH Mochammad, Kelurahan Mekar Sari, Kecamatan Tambun Selatan, Bekasi, 17510, dan berjarak $\pm 31 \mathrm{Km}$ dari Kampus B, Universitas Indraprasta PGRI.

Sasaran utama kegiatan adalah pendidik pada pendidikan tingkat menengah kejuruan. Kegiatan dilaksanakan dengan menggunakan metode pelatihan. Metode pelatihan yang dimaksud adalah memberikan materi dan teknis pelaksanaan dalam memanfaatkan teknologi pada pembelajaran. Tiga tahap yang dilakukan dalam kegiatan ini, diantaranya adalah :

1. Persiapan

Tim pelaksana melakukan survei terlebih dahulu untuk mengetahui lokasi, situasi dan kondisi mitra di lapangan, menyusun kegiatan yang dilakukan, mempersiapkan bahan dan perlengkapan yang digunakan, serta strategi penyampaian materi yang tepat.

2. Pelaksanaan

Tim pelaksana mempresentasikan dan memberikan pemahaman materi, serta mempraktekkan cara penggunaan aplikasi teknologi pembelajaran.

3. Evaluasi

Tim Pelaksana melakukan evaluasi dengan menanggapi respon, saran dan kritik peserta kegiatan pengabdian kepada masyarakat

Mitra dari tim pelaksana berpartisipasi dalam mempersiapkan waktu yang dibutuhkan pada pelaksanaan kegiatan pelatihan. Mitra sangat berantusias untuk mengikuti kegiatan pelatihan yang akan dilakukan tim pelaksana tersebut, mengingat materi yang akan dipaparkan sangat bermanfaat bagi mereka para pendidik dalam meningkatkan hasil pembelajaran yang dapat meningkatkan mutu lembaga pendidikan.

\section{HASIL DAN PEMBAHASAN}

Kegiatan ini dilaksanakan secara daring pada tanggal 22 Oktober 2020, melalui zoom meeting yang dimulai dari jam 07.00 WIB sampai dengan jam 13.00 WIB. Kegiatan terlaksana dengan baik dan lancar, karena mengacu pada permasalahan mitra dan hasil analisis survei yang dilakukan oleh tim pelaksana terhadap mitra. Pendidik SMK Telekomunikasi Telesandi, Bekasi, yang berjumlah 16 orang hadir berpartisipasi dalam kegiatan, termasuk kepala sekolah.

Pelaksanaan kegiatan ini terbagi menjadi tiga tahap. Tim pelaksana pada tahap pertama mempresentasikan mengenai peningkatan pembelajaran matematika melalui literasi digital, yang meliputi : pendahuluan, bagaimana meningkatkan pembelajaran matematika melalui literasi digital, serta beberapa jenis dan cara penggunaan aplikasi teknologi dalam pembelajaran matematika. Kegiatan yang dilakukan pada tahap kedua, tim pelaksana memandu pemahaman peserta kegiatan secara sekilas mengenai beberapa aplikasi teknologi yang dapat digunakan dalam pembelajaran matematika, sehingga materi pembelajaran matematika menjadi menarik, mudah dan cepat dipahami, serta dapat meningkatkan kreativitas dan memotivasi peserta didik untuk terus meningkatkan 
ilmu pengetahuan, keterampilan dan hasil belajar pada pembelajaran matematika. Tahap ketiga sebagai penutup, tim pelaksana memberikan kesadaran kepada peserta kegiatan agar terus bersemangat dalam meningkatkan hasil pembelajaran yang selanjutnya akan meningkatkan mutu pendidikan.

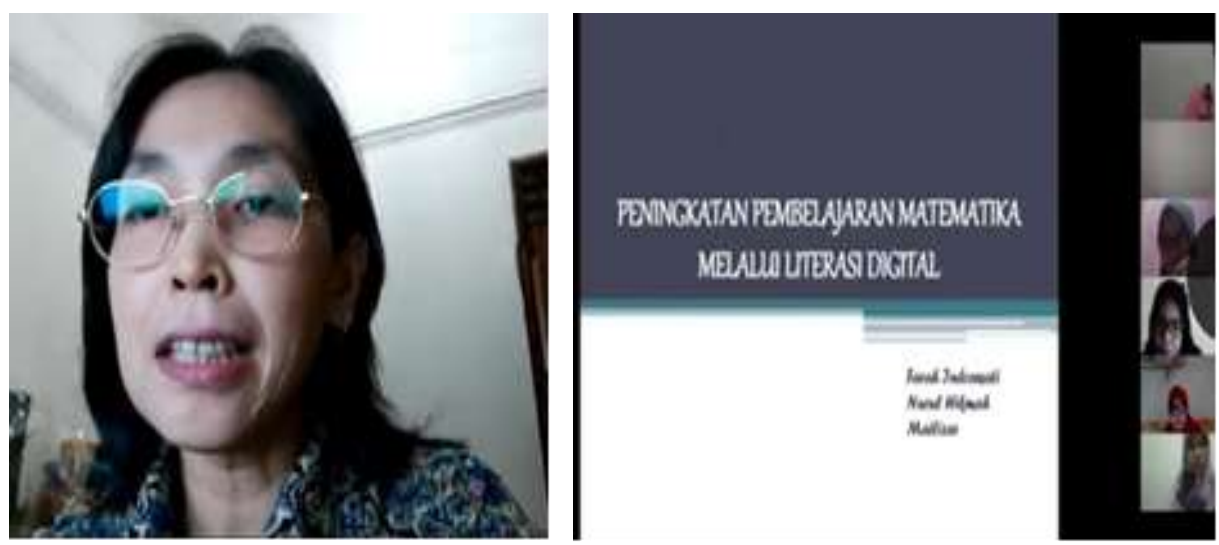

Gambar 1. Presentasi Materi pada Pelaksanaan Kegiatan

Tiga tahap kegiatan tersebut dikemas dengan menarik agar peserta kegiatan tidak mengalami kejenuhan dalam mengikuti proses pelatihan yang berlangsung selama \pm 6 jam. Peserta kegiatan terlihat sangat antusias dan responsif dalam mengikuti rangkaian kegiatan pelatihan, karena diberikan kesempatan untuk mengungkapkan pertanyaan dan berbagi pengalaman, serta menyampaikan pendapat dan tanggapan selama kegiatan berlangsung. Peserta kegiatan memberikan respon positif dan usulan kegiatan selanjutnya mengenai berbagai jenis aplikasi pembelajaran matematika yang dapat digunakan dalam semua materi pembelajaran matematika di lembaga pendidikan.
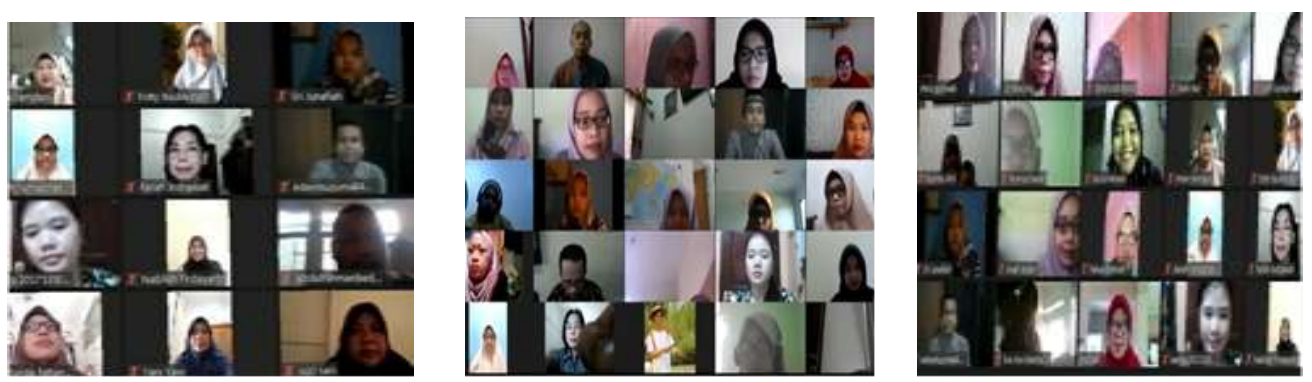

Gambar 2. Kondisi Peserta pada Pelaksanaan Kegiatan

Pelaksanaan kegiatan diikuti oleh pendidik SMK Telekomunikasi Telesandi, Bekasi. Keikutsertaan pendidik tersebut disebabkan oleh adanya sistem pembelajaran yang menuntut pendidik harus terus belajar dan dapat menyampaikan materi pembelajaran dengan melibatkan segenap kemampuan yang dimilikinya. Kemampuan tersebut tentunya harus disesuaikan juga dengan perkembangan zaman yang terus mengalami perubahan. Kemampuan menggunakan perangkat teknologi, informasi, dan komunikasi harus didukung oleh kemampuan bersosialisasi, memahami pembelajaran, bersikap, berpikir kritis, dan kreativitas. Pendidik harus mempunyai keseluruhan kemampuan tersebut, sehingga dapat menggunakan aplikasi teknologi secara tepat dan sesuai dengan yang harus dipelajari oleh peserta didik, khususnya pada pembelajaran matematika. 
Tujuan pada tahap pertama pelaksanaan kegiatan ini adalah memberikan pengetahuan dan pemahaman tentang latar belakang, tujuan dan cara meningkatkan pembelajaran matematika melalui literasi digital, serta berbagai aplikasi dan contoh aplikasi pembelajaran matematika yang dapat diterapkan sehingga dapat meningkatkan hasil pembelajaran matematika peserta didik. Tahap kedua bertujuan untuk mengembangkan pengetahuan dan ketrampilan peserta kegiatan dalam meningkatkan pembelajaran matematika melalui beberapa aplikasi pembelajaran matematika, seperti : photomath, qanda, microsoft math solver, math master, dan mathway. Peserta kegiatan pada tahap kedua ini diharuskan meningkatkan pengetahuan dan kreativitasnya dengan menguasai konsep materi pembelajaran dan aplikasi teknologi yang ada dalam waktu yang terbatas. Selanjutnya, tim pelaksana kegiatan membangkitkan kesadaran peserta kegiatan pada tahap ketiga untuk terus bersemangat meningkatkan pembelajaran matematika dengan meningkatkan kemampuan, ilmu pengetahuan, dan keterampilan melalui literasi digital, sehingga mutu pendidikan dapat ditingkatkan. Beberapa tahapan tersebut dilakukan untuk menghindari miskonsepsi dalam pembelajaran dan teknologi sebagai media pembelajaran.

Rasa keingintahuan yang tinggi menimbulkan keantusiasan peserta pelatihan untuk mengikuti semua tahapan yang terdapat pada pelatihan tersebut. Peserta pelatihan masih banyak yang belum, bahkan tidak mengetahui tentang bagaimana cara meningkatkan pembelajaran matematika melalui literasi digital yang memanfaatkan aplikasi teknologi sebagai media pembelajaran. Terlebih lagi dalam pelaksanaan ini, tim pelaksana kegiatan memberikan beberapa contoh aplikasi pembelajaran matematika yang memudahkan pendidik untuk dapat terus melakukan tugas utamanya memberikan pembelajaran secara menarik dengan membangun pola pikir kritis yang dapat meningkatkan ilmu pengetahuan dan keterampilan, kapanpun dan dimanapun berada.

Kegiatan ini menyadarkan peserta kegiatan bahwa sebagai pendidik harus selalu dan terus menggali atau menambah ilmu pengetahuan dan keterampilan, serta meningkatkan dan mengembangkan potensi diri. Kompetensi pendidik tentunya merupakan suatu hal yang sangat penting dan dibutuhkan dalam pembelajaran untuk meningkatkan hasil belajar peserta didik. Pembelajaran yang kondusif, bermakna dan bermutu, tentunya membutuhkan adanya pemahaman pendidik mengenai penggunaan teknologi pembelajaran yang merupakan salah-satu prasyarat kecakapan hidup saat ini. Pendidik harus aktif dan kreatif terus menyesuaikan pembelajaran dengan memanfaatkan teknologi secara bijak sebagai media pembelajaran produktif tanpa meniadakan interaksi dengan peserta didik, terutama pada saat ini di era globalisasi yang telah mengubah budaya literasi individu menjadi literasi digital.

\section{SIMPULAN}

Kesimpulan dari kegiatan yang dilakukan adalah pendidik SMK Telekomunikasi Telesandi menyadari pentingnya literasi digital dalam peningkatan pembelajaran matematika. Ilmu pengetahuan dan ketrampilan pendidik yang dielaborasikan dengan fasilitas teknologi yang memadai dapat memudahkan pendidik untuk mengelola pembelajaran menjadi menarik, menyenangkan, tidak membuat kebosanan, tanpa batasan jarak, dan atau waktu. Beberapa contoh penggunaan aplikasi pembelajaran matematika yang diberikan pada saat presentasi dalam kegiatan tersebut membuka wawasan peserta kegiatan atau pendidik SMK Telekomunikasi Telesindo untuk terus 
menyesuaikan diri dengan perkembangan teknologi yang ada dalam mengelola pembelajaran, sehingga dapat melahirkan generasi penerus yang produktif, sesuai dengan yang dibutuhkan pada zamannya.

\section{DAFTAR PUSTAKA}

Amirul Huda, F. 2019. Pengertian Pembelajaran Matematika. http://fatkhan.web.id/pengertian-pembelajaran-matematika/

Emre Çam and Mübin Kiyici. 2017. Perceptions of Prospective Teachers on Digital Literacy. Malaysian Online Journal of Educational Technology.

Kementerian Pendidikan dan Kebudayaan. 2017. Materi Pendukung Literasi Digital. Jakarta. https://gln.kemdikbud.go.id/glnsite/wp-content/uploads/2017/10/covermateri-pendukung-literasi-digital-gabung.pdf

Muliawanti, S., Anggun Badu Kusuma. 2019. Literasi Digital Matematika di Era Revolusi Industri 4. 0. Prosiding SENDIKA, 5(1), Hal 317-323.

National Council of Supervisors of Mathematics (NCSM). 2015. Mathematics Education in the Digital Age. Irist Project: Focusing on Digital Mathematics Education.

Ramadhan, B. 2020. Data Internet di Indonesia dan Perilakunya Tahun 2020. https://teknoia.com/data-internet-di-indonesia-dan-perilakunya-880c7bc7cd19

Sahaja, I. 2014. Pengertian Pembelajaran Matematika. https://irwansahaja.blogspot.com/2014/06/pengertian-pembelajaranmatematika.html

Tim PRFM. 2020. Enam Literasi Dasar yang Harus Anda Ketahui. Pikiran Rakyat. https://prfmnews.pikiran-rakyat.com/lifestyle/pr-13804800/enam-literasi-dasaryang-harus-anda-ketahui? page $=2$

UNESCO. 2011. Digital Literacy in Education. UNESCO Institute for Information Technologies in Education. IITE Policy Brief.

Wardhani, V. 2020. Apa itu Literasi ? Simak 3 Pengertiannya menurut Institusi Dunia. Merdeka - Jatim. https://www.merdeka.com/jatim/apa-itu-literasi-simak-3pengertiannya-menurut-institusi-dunia-kln.html?page=all 